\title{
Empowerment of Kader Kesehatan Jiwa (KKJ) through RW Siaga Sehat Jiwa (RW SSJ) in Bandarharjo Semarang
}

\author{
${ }^{1}$ Dwi Heppy Rochmawati*, ${ }^{2}$ Wahyu Endang Setyowati, ${ }^{3}$ Betie Febriana, \\ ${ }^{4}$ Wigyo Susanto \\ ${ }^{1,2,3,4}$ Department of Nursing, Faculty of Nursing University of Islam Sultan Agung \\ Semarang \\ *Corresponding Author \\ dwiheppy@unissula.ac.id
}

\begin{abstract}
Health is an investment to improve the quality of human resources. Both physically and psychologically healthy. The mental nursing area includes giving care to healthy mental, client and mental disorders clients. Mental health services are no longer focused on healing clients of mental disorders, but also on efforts to promote mental health or prevention efforts. This effort can be carried out by health workers and community participation through community empowerment. Community empowerment of mental health can be achieved with a health service management especially community-based mental health services. This form of health care management approach is known as Community Mental Health Nursing $(C M H N)$. The purpose of this community service is to realize the formation of $R W$ Siaga Sehat Jiwa (RW SSJ) with the participation of the Mental Health Cadre $(K K J) . R W$ SSJ is a forum for the KKJ to carry out activities and apply the abilities obtained through training. With the increasing ability of the KKJ in overcoming health problems, it is hoped that the community can play an active role in realizing health status in their environment. The method used is the nursing process approach. It is expected that the KKJ has the ability to carry out early detection, determine family status and care for family risks and disorders, refer cases to health centers and or hospitals.
\end{abstract}

Keywords: Mental health cadre, RW Siaga Sehat Jiwa, community mental health nursing.

\section{INTRODUCTION}

Health is an investment to improve the quality of human resources. Law No. 36 of 2009 concerning health stipulates that health is a prosperous condition of the body, soul and social which allows every person to live productively socially and economically. This gives the meaning that health must be seen holistically and mental health is a part of health that cannot be separated. Mental health services are no longer focused on healing clients of mental disorders, but also in efforts to promote mental health or prevention 
efforts with targets other than clients of mental disorders, including clients with chronic diseases and healthy individuals as preventive efforts. This effort is not only carried out by health workers but also by community empowerment through activities that provide understanding, foster awareness and awareness of the community towards mental health problems of its citizens.

Efforts to empower the community towards mental health can be achieved with a health service management, especially community-based mental health services. This form of community mental health service management approach is known as Community Mental Health Nursing (CMHN) (Keliat, et al, 2007). The CMHN program was first developed in the provinces of Nangroe Aceh Darussalam (NAD) and Nias when the province experienced the Tsunami disaster in 2004. This program has been successful in overcoming mental health problems of the people of NAD and Nias due to post-disaster. Based on the success of the CMHN program, several regions that were also affected by the earthquake in 2009, namely in Bengkulu, Tasikmalaya and Padang City, West Sumatra Province, also carried out a CMHN program to prevent and restore psychosocial problems of victims of the disaster. In October 2010 the CMHN program was also carried out on disaster victims due to the eruption of Mount Merapi in the City of Magelang and Yogyakarta. The activities and success of the CMHN program indicate that the program has been effective in restoring mental health problems to clients who are still in the community, both clients who have experienced mental disorders and clients who still experience psychosocial problems or clients who have a risk of experiencing mental disorders.

Based on the Basic Health Research Results in 2018 it was found that the number of National Severe Mental Disorders was $7 \%$; the number of mental emotional disorders (Risk) is $9.8 \%$. The CMHN program aims to improve healthy mental health of people, prevent disruption in groups of people who are at risk or vulnerable and restore mental disorders to be independent and productive. This activity was carried out with the community, especially TOMA (community leaders) and TOWA (community leaders) who were trained to become mental health cadres. The family is the spearhead and the main partner in realizing a healthy family of souls and subsequently a healthy community of the soul. Many factors influence the success of mental health services, 
including the existence of stigma about mental disorders, lack of sufficient information about mental disorders, and limited access to services (Mohr, 2006).

One of the implementations to get access to information and services is to realize RW healthy mental alert. The healthy mental alert (RW SSJ) program realized by the formation of the Mental Health Cadre (KKJ) is expected to be one of the media to approach the access to mental health services through the integration of services at the basic level. The purpose of this community service is to establish a Mental Health Cadre, to realize the RW Siaga Sehat Jiwa, to improve the knowledge of the Mental Health Cadre about the introduction and detection and management of clients mental disorders, risks and mental health with assistance.

\section{METHOD}

The activities carried out / solutions offered in overcoming the above problems are community empowerment through the establishment of mental health cadres in RW 10, Bandarharjo Village. Method of approach using the method of "Nursing Process" (Nursing Proces Method). These activities include: assessment, problem determination, planning, action and evaluation.

Assessment is carried out covering the population, health conditions of the population, availability of supporting facilities and facilities. Included in this study was the motivation of residents to participate in realizing mental health in the RW 10 area. The study ended with the formulation of health problems that occurred in the community of RW 10 in Bandarharjo village.

Planning based on the findings of the problem, including: the realization of RW Siaga Sehat Jiwa (presentation on the concept of RW Alert healthy, brain storming, RW inauguration to become RW healthy mental alert); strategies to overcome mental health problems by establishing Mental Health Cadres in Bandarharjo sub-district (identification of potential cadre abilities, cadre training, assistance in implementing activities for cadres)

Actions / implementation of activities carried out: implementing the RW Siaga Sehat Jiwa formation program; early detection of healthy families, families at risk of experiencing psychosocial problems and groups of families with mental disorders in the 
community; move individuals, families and groups healthy mental, risk and mental disorders to attend mental health education; conduct training of KKJ (Mental Health Cadres) for cadres in Bandarharjo Village; make home visits in patients who are independent; referring cases of psychosocial problems or mental disorders to the local health center; documentation of mental health cadre activities.

The evaluation was carried out to identify the ability of the Mental Health Cadre to carry out early detection and management of healthy clients, risks and disorders. Identify the condition of healthy mental clients to stay healthy. Clients or families at risk get treatment so that they do not experience mental disorders and evaluate mental disorders clients have received treatment and treatment.

The community service partner on this occasion was the KKJ (Mental Health Cadre) which was formed in the Bandarharjo Sub-District of North Semarang District. Partner participation in the implementation of community service starts from assessment, planning, implementation and evaluation, according to the method used, namely the Nursing Process method. In more detail, partner participation is as follows: The KKJ formed is involved in identifying mental health problems in the community; The KKJ participates as a participant in the KKJ training; The KKJ is involved in realizing RW SSJ (Healthy Healthy Alert) through case finding, management of healthy clients, risks and disorders.

\section{RESULTS AND DISCUSSION}

\section{Results}

1. Population percentage based on gender

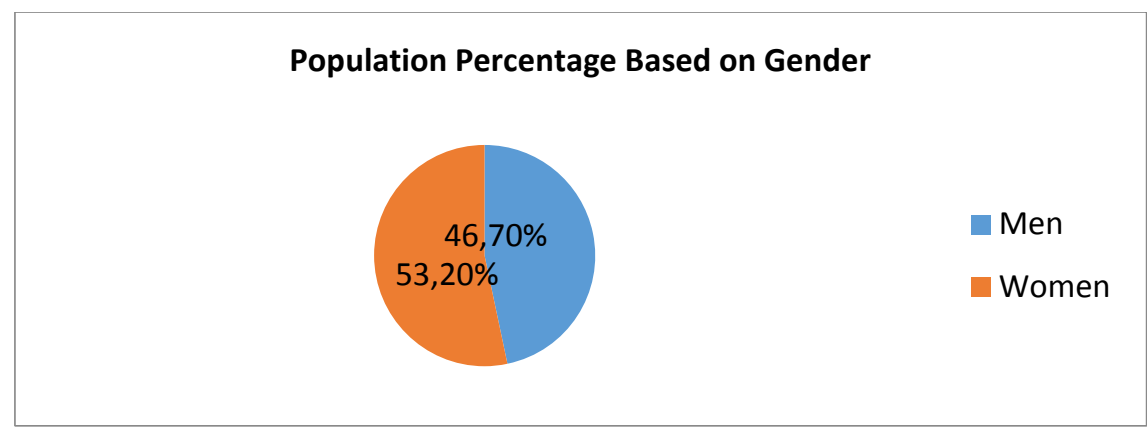

Figure 1. Population Percentage Based on Gender 
Based on the figure 1 above, the number of male population is 453 people (46.70\%) and the female population is 517 people (53.20\%) of the total population.

2. Population percentages based on age levels

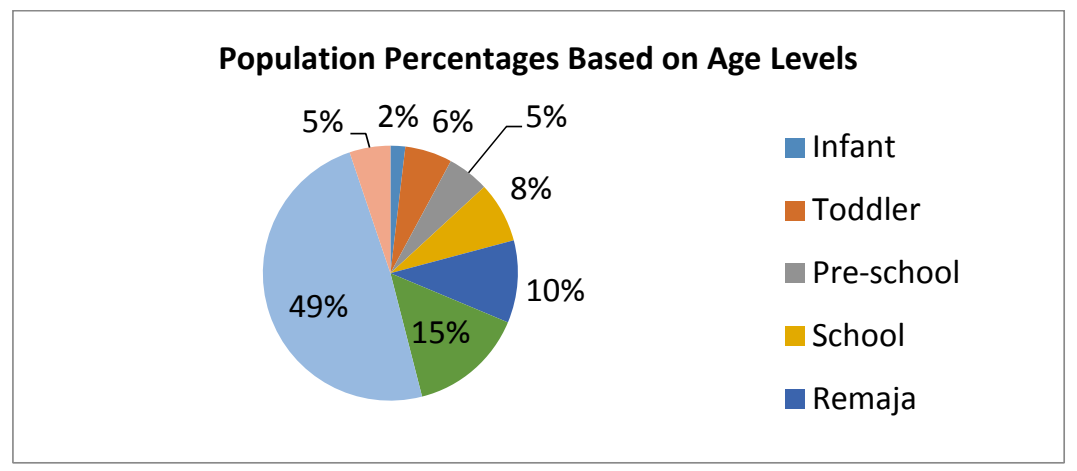

Figure 2. Population Percentages Based on Age Levels

Based on the figure 2, the population of infants ( $0-18$ months) as many as 18 people (2\%), toddler age (19 months-3 years) as many as 58 people (6\%), preschool age (4-6 years) as many as 51 people (5\%), school age (7-12 years) as many as 74 people ( $8 \%)$, teens (13-18 years) as many as 101 people (10\%), early adulthood (19-22 years) as many as 142 people ( $15 \%$ ), middle adulthood (23-65 years) as many as 471 people (49\%) and elderly (> 65 years) as many as 50 people (18\%).

3. Population percentage based on the findings of the problem

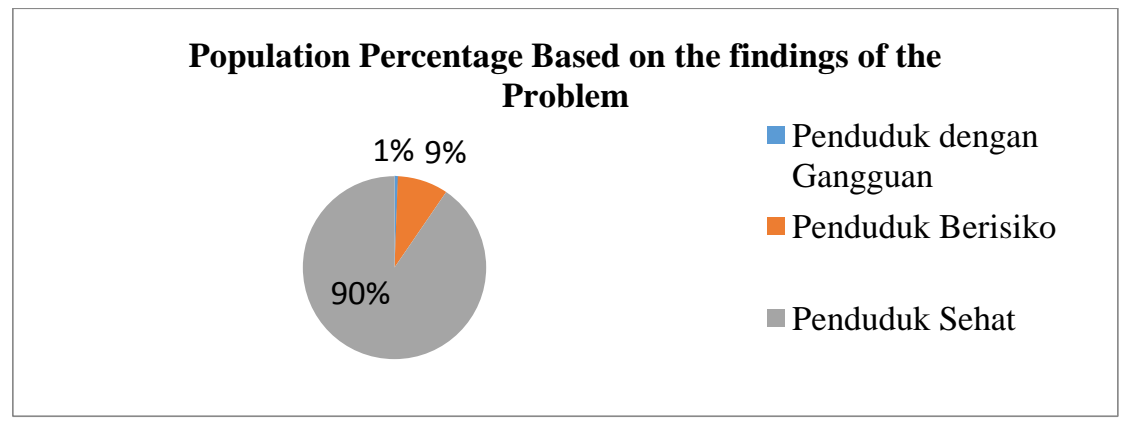

Figure 3. Population Percentage Based on the Findings of the Problem

Based on the figure 3 above it is known that the population experiencing disruption is 6 people (1\%); residents at risk of experiencing disorders numbered 87 people (9\%) with 
anxiety problems, helplessness, situational low self-esteem, and despair; healthy soul population is 877 people $(90 \%)$.

\section{Discussion}

The step taken after identifying residents is to provide understanding to residents regarding RW Siaga Sehat Jiwa. This activity was carried out by brain storming, giving an explanation to the community regarding RW Siaga Sehat Jiwa with material presentation and question and answer and discussion. RW Siaga Sehat Jiwa is an RW that has a healthy soul, is aware of mental health problems, wants and is able to prevent and overcome mental health problems that threaten the community. Able to provide health services provided from, by and for the community using existing service facilities.

Then identify the ability of citizens who are willing to take the time to become Mental Health Cadres who will mobilize their citizens to pay attention to and provide management for mental health problems. The cadres were selected with a ratio of 1 cadre to 20 family heads, filling out informed consent and then being given cadre training. The requirement to be a cadre is to get permission or blessing from a spouse (husband / wife), be willing to take the time to provide health assistance, be able to read and write, be willing to coordinate with religious leaders and the community, in collaboration with the puskesmas.

Cadre training was carried out for 2 days followed by assistance in field practice. Cadre training materials provided are early detection of mental health problems, documentation of detection results, mobilizing the community to attend health education on risk and disruption issues, implementing patient referrals and implementing home visits. All results of the activity are documented in the assisted book prepared. There are 4 (four) auxiliary books prepared, namely cadre handbooks: family detection; cadre handbook: mental health counseling; cadre handbook: supervision of mental patients; reference book.

After attending the training, trained cadres practiced in the field with assistance. The activities carried out by cadres are early detection of the community and documentation. Early detection is carried out by cadres to find out and identify mental 
health conditions in the community. Grouping people in the mental health category, risk categories for mental disorders or experiencing psychosocial problems or mental emotional disorders and mental disorders categories.

Families included in the mental health group have characteristics such as those stated by Maslow, namely: having a perception of the right reality, being able to accept themselves, others and human existence, being able to show spontaneity, have privacy needs, have independence and autonomy, have the intensity of emotional reactions, experiencing / feeling the wealth and beauty of life, being able to identify human goodness. Families in the mental health category are grouped in the infant age group (018 months), toddlers (18 months - 3 years), pre-school (3-6 years), schools (6-12 years), adolescents (12-18 years ), adults (18-25 years), middle adults (25 - 60 years) and elderly> 60 years.

Whereas families who are categorized as having a risk of mental disorders are families that have characteristics: experiencing loss of limbs, loss / separation from loved ones; loss of job, property, residence, school; families with chronic diseases: tuberculosis, hypertension, diabetes, heart, kidney and rheumatic diseases; family with pregnant women or mothers giving birth. Families that have family members with these conditions are categorized into risk problems because they require handling and assistance in dealing with the problems. If you don't get the right assistance and handling, you will be at risk of experiencing mental emotional problems.

Families that are categorized as mental disorders are families that have family members who experience mental disorders. Mental disorders are disturbed thoughts, behavior and feelings, so that individuals are different from ordinary people. The characteristics of a person experiencing a mental disorder are experiencing prolonged sadness for a long time (more than 2 weeks); the ability to carry out daily activities (cleanliness, eating, drinking, activity) decreases; motivation to do declining activities (lazy); angry without cause; talk or laugh alone; rampage; ; aloof; do not want to hang out; not paying attention to appearance / personal hygiene; say or attempt suicide. 


\section{CONCLUSION}

RW Siaga Sehat Jiwa has been formed through Community Empowerment, namely Cadre of Mental Health. The number of KKJ who have participated in the training is 25 people. Increased ability of the KKJ in terms of early detection of mental health, moves the masses to take part in mental health counseling activities, home visits and referral of mental health cases to health centers and or hospitals through KKJ training and mentoring.

The creation of a healthy population remains healthy through the role of the KKJ, prevents mental health problems in people who experience chronic physical illness who are at risk of mental health problems through counseling and training, patients who have experienced mental disorders become independent and productive. A total of 6 mental disorders clients have received treatment. The risk clients as many as 87 people were identified as having received 24 treatments. A total of 6 families with impaired clients have been trained to take care of clients and as many as 24 families at risk of being trained in treatment.

\section{ACKNOWLEDGMENTS}

1. Sultan Agung Islamic University, Semarang.

2. UNISSULA Research and Community Service Institution for the opportunity and grant given to the author.

3. Dean of the UNISSULA Nursing Faculty along with staff who have provided support.

4. The entire community service team of the mental nursing department of the Faculty of Nursing UNISSULA

5. Head of Bandarharjo Subdistrict, North Semarang Subdistrict along with all staff and staff who have given permission and opportunities to the author.

6. Chairperson of the RW in Bandarharjo Sub-District, North Semarang Subdistrict, as a community service area and all its equipment.

7. Chairperson of the Mental Health Cadre and all Mental Health Cadres in Bandarharjo Sub-District, North Semarang District. 
8. Religious Leaders and Community Leaders of Bandarharjo Village who participated in this community service.

9. All communities in Bandarharjo village during community service.

10. All parties that the author cannot mention one by one.

\section{REFERENCES}

Departemen Kesehatan Republik Indonesia. (2018). Hasil Riset Kesehatan Dasar. Jakarta.

Dirjen DIKTI. (2013). Panduan Pelaksanaan Penelitian dan Pengabdian kepada Masyarakat di perguruan Tinggi. Edisi IX. Jakarta. FKM UI. tidak dipublikasikan.

Keliat, B.A. \& Akemat. (2007). Model Praktik Keperawatan Profesional Jiwa. Jakarta: Penerbit Buku Kedokteran EGC.

Keliat, B.A. (2003). Pemberdayaan klien dan keluarga dalam perawatan klien skizofrenia dengan perilaku kekerasan di RSJP Bogor. Disertasi. Jakarta.

Keliat, B.A. (2011). Keperawatan kesehatan Jiwa Komunitas. CMHN (Basic Course). Jakarta : EGC.

Keliat, B.A. (2011). Manajemen Kasus gangguan Jiwa. CMHN (Intermediate Course). Jakarta : EGC.

Keliat, B.A. (2011). Manajemen Keperawatan Jiwa Komunitas Desa Siaga. CMHN (Intermediate Course). Jakarta : EGC.

Keliat, B.A. (2011). Manajemen Keperawatan Psikososial dan Kader Kesehatan Jiwa. CMHN (Intermediate Course). Jakarta : EGC

Maramis, W.F. (2006). Catatan Ilmu Kedokteran Jiwa. Surabaya : Airlangga Universitas Press.

Mohr, W.K. (2006). Psychiatric Mental Health Nursing. Philadelphia : Lippincot. Nugroho, P.A. (2014). Laporan Asuhan Keperawatan Jiwa Komunitas. Tidak dipublikasikan.

Nursalam. (2002). Manajemen Keperawatan dan Aplikasi dalam Praktik Keperawatan Profesional. Jakarta : Salemba Medika.

Rochmah, Y.S., \& Fasitasari, M. (2014). IbM kelurahan Penggaron Lor dengan Pemberdayaan Ibu Rumah Tangga Melalui PKK dam Pemberdayaan Tanaman 
Indonesian Journal of Community Services

E-ISSN: 2684-8619

Volume 1, No. 1, May 2019

http://jurnal.unissula.ac.id/index.php/ijocs DOI: http://dx.doi.org/10.30659/ijocs.1.1. 73-82

Pisang sebagai Media untuk Menjaga Kesehatan Gigi dan Mulut. Semarang : UNISSULA.

Stuart, G.W. \& Laraia, M.T. (2005). Principles and Practice of Psychiatric Nursing. Eight Edition. St. Louis : Mosby.

Suliswati, dkk. (2005). Konsep Dasar Keperawatan Kesehatan Jiwa. Jakarta : EGC

Tomey, A.M., \& Alligood, M.R. (2006). Nursing Theorists and Their Work. Sixth Edition. St. Louis : Mosby.

Undang-Undang Republik Indonesia Nomor 36 Tahun 2009 Tentang Kesehatan.

Viedebeck, S.L. (2008). Buku Ajar Keperawatan Jiwa. Alih Bahasa oleh Renata Komalasari dan Alfrina Hany. Jakarta : EGC. 